\title{
Ruby, Wanda and Me, Late at Night, in the County Jail
}

I loved him more than I loved yellow seahorses and red anemones and glass-hearted frogs put together, and when I was with him, I thought of myself as Psyche with a bosom full of fish or as Daphne, her hair in wild disarray. I don't know if you could say we were ever happy together. It seemed like happiness, but it was more like the excitement of infatuation combined with insecurity, jealousy, and the tantalizing prospect of reforming him. I never imagined I'd turn on him, but Psyche's wings got burnt and Eros somehow got immolated by his own principle, fire.

Eventually he joined the Air Force and was shipped off to Ellsworth Air Force Base in South Dakota; I got pregnant and had his baby. Then I was arrested and convicted and sent to the Federal Correctional Facility in Alderson, West Virginia.

His name was Theodore St. Clair, but I called him T-Bone. We met at the Mount Abrams Military Academy at the corner of Riverside Drive and noth Street, where, every Thursday after school, I created quite a sensation by lying across the doorway in my skeleton costume so that every young warrior coming out of school had to step over me. One day, Theodore stopped, took my hand, yanked me to my feet, told me the police were on the way and suggested I do something legal with my passions.

"Dioxin is legal," I said. "Nuclear bombs are legal. War is legal."

I could see that he was a leader and probably a nonconformist because he was the only one in the school who had managed to hang onto his hair. He walked me to the end of the path and offered me a ride on his motorcycle, and from then on, every afternoon, I found myself wandering out of school in my grey and blue St. Ursula's uniform with a scapular of the Blessed Virgin around my neck, jumping onto Theodore's motorcycle, and disappearing into a trail of smoking sin.

"Pet your dog, not your date," my father said, and the billboard up on Broadway advised, A tisket, a tasket, a condom or a casket. But I felt myself looking underneath Theodore's military husk and seeing a 
man who with a little encouragement could learn to despise Apache helicopters and B-52's as much as I did.

"What have our parents done for the planet, actually?" I said to him one day. "All that stuff in the sixties about love and peace. Now you know what they talk about every night? Their health. My father takes better care of his Audi than he does of me. The Cold War is over, but the Pentagon is still spending 35 billion dollars a year on nuclear bombs, and no one really talks much about it."

"You do," he said.

"Gandhi said it's easy to wake a sleeping man but it's impossible to wake a man who's pretending to sleep."

"Our nuclear arsenal is keeping us safe," he said.

"I don't feel very safe. And how are we going to break it to the next generation and the four hundred generations after that that they're going to have to take very good care of our nuclear waste?"

He wasn't really listening to me, but I didn't notice this because no one except our housekeeper Mary had ever really listened to me. My mother called me the awfullizer. My father called me the instigator.

I ran my fingers over his glossy brown hair, imagining him as a Buddhist monk getting up at four o'clock every morning to shave his head and practice zazen. I imagined traveling around the country together in our earth ambulance, wearing white jackets with big red crosses painted on the back. But instead, one day he announced in his brusque general's voice that he did not expect to see me clad in my skeleton costume until next Halloween.

"How come?" I said.

"Because I'm getting tired of tripping over you on my way out of school. It's becoming a real bore. And I'm starting to hear about it from the guys."

"Someone once said that it isn't the rebels that cause the troubles, it's the troubles that cause the rebels."

"Just get rid of the costume, okay?" he said.

"Okay," I said.

"Do you think obedience is a virtue?" I said to him one day in Burger King where we were surrounded by the shining blue and yellow and red and orange plastic of the real world.

"Society would be immobilized without it," he said, popping a French fry into his mouth. 
"Maybe it would be healthy for society to be immobilized. It would give us a minute to look around and notice how sheeplike we all are, and wonder who the shepherd is and where exactly he's leading us."

"There's no room for disobedience in the military," he said. "We're a team. We think together, not individually. Our strength is in collectiveness."

"But groups of people have never been especially moral, have they?" I said. "Isn't it usually individuals who are the moral ones?"

"If defending your country isn't a moral act, I don't know what is."

"Speaking up for the unborn?" I suggested. "Being a voice for the voiceless?"

"Oh baby," he said, nuzzling his face into my hair. "You are just bow-wows."

I watched him eating for a while. "I think it's all those cows you eat that's contributing to your militaristic tendencies," I said. "Cows are terrified when they're killed in the slaughterhouse, and you end up eating their fight-or-flight response." His teeth dug into the pinkish-brown patty that had once, with all its heart, loved grass.

But it did not really matter to me what he ate, what he thought, what he said, or what he did. I loved him, and that's what love is: a bunch of potions, spells, and enchantments whose only goal is to assure the survival of the species.

Before I was sent to Alderson, I was in the county jail, and no one there was as kind to me as Wanda. Wanda was in for prostitution, although it seemed strange to me that society was always encouraging a woman to be a sex symbol but when she started to act like one, she ended up in the county jail. (And her partner didn't.)

Some days, it felt relaxing to sit and count the chinks in the cinderblocks, but other days, I'd start to cry, thinking about Alvy. Ruby (a jewel thief) kept saying, "Will you quit yawping?" but I'd keep crying, thinking of my baby being without me. He was getting wonderful care from Mary, who grew up in Greenland and was strong as a musk ox, smart as a raven and warm as a polar bear. But I missed him, and sometimes I cried and cried, and Wanda always got up and stood by my bunk, patting my back and smoothing out my hair until I fell asleep. 
"You have a sulky kind of virginal look," she said to me one day when we were sitting around in the dayroom. "I can almost see you joining my escort service." She had a face like a puppy and these happy, frantic brown eyes.

"Wanda, my father works for NASA. My mother plays the violin at Lincoln Center. People like me get upset about the idea of a woman selling her body to a man."

"It's a free country, right?" Wanda said.

"I don't really know," I said.

Unfortunately, Ruby was allergic to nature and the flowers I picked from the edge of the exercise yard made her sneeze. I loved flowers. She hated them. She loved jewels. I hated them. I loved spiders. She hated them. She hated jail. I partly liked it because everybody knew the worst stuff about you and it didn't faze them. People outside are mad at you for being who you are. They try to dress it up or dress it down, but in jail, you're you. I could tell Wanda the most shocking thing and all she'd say is, "For Pete's sake." Ruby would just shrug or, if she wasn't feeling irritable, she might say, "Uh-huh."

One day, I sat down and figured out that the Pentagon spends forty-five million dollars an hour, and a billion dollars a day. I told Ruby, and she seemed to think this was hilarious. Her graty cigarette cough laugh started bouncing off the cement block walls. She was thin and bony, with penciled-on eyebrows and a clump of shiny orange hair hanging like a donut over one ear. I sat trying to ignore her laugh, doing my alternate nostril breathing technique. She turned to me and said, "What's a sucking-up white girl like you doing in a place like this? What are you, one of them yuppies? Stop smoking and eat tofu?"

"I'm here because I tried to steal a Sherman tank."

"A Sherman tank," she sneered. "Is that kind of like a Bergdorf mink? I could see stealing a Mercedes. Or a BMw."

I remembered Alice Walker saying that growth requires us to become intimate with what is foreign, and Ruby and I were foreigners. I pictured her lying in her bunk, dreaming of a future filled with diamonds, minks, and rich men, while I lay in mine, dreaming of a future filled with clean air, clean water, and green grass. 
One day, when I was hanging flowers and paper streamers in our cell and trying to give Ruby some lessons in feng shui, she told me how she had gotten her daughter to swallow a diamond for her.

"Was she getting tired of cheeseburgers?" I said.

"She was helping her old lady out, dumbo."

"Aren't diamonds poisonous?" I said.

"They're full of B vitamins."

"Your daughter must have a lot of courage. I'd never do anything like that for my mother."

"It takes fear to swallow a diamond-not courage," she said.

"Have you ever told your daughter how much of your tax dollar goes to the military?"

"People like you would benefit from being illiterate," she said.

"Eight cents for health, two cents for food and nutrition, one cent for social services, two cents for education, and fifty-two cents for the military," I said. "They're your tax dollars, Ruby."

Ruby raised her eyebrows and looked over at me. "There ain't no tax on stolen jewels, butthead."

One day while I was still in the county jail, T-Bone came to visit me. He was wearing his Air Force uniform, and I sat across the table from him in my prison uniform (which was similar to my skeleton suit) and wondered what I had ever seen in him. He looked kind of boiled without all the hair I used to love running my fingers through and sort of blue-white and sun-starved, like he had been sitting underground with his finger on the nuke button.

"Hi, Raine," he said.

"Howdy, Theodore."

"How are you, Raine? You look pretty good, considering the fact that they've stashed you away in the Crowbar Hotel."

"I'm okay," I said.

"How's Alvy?" he said.

"Who?"

"Alvy. Our son."

"I don't know who you're referring to, Theodore."

"Raine, you have no right to keep me away from my own flesh and blood. I know you're mad at me for wanting to-you know. But we were just kids, too young to be parents."

"You tricked me," I said. 
"You tricked me. Suddenly you waltz up to me with this whole trip about me becoming a father."

"It wasn't a trip. It was a pregnancy. Jeez, T-Bone, here I thought you were this guy who cared about the planet. I thought you loved those seals we saw in Central Park. I thought you had nightmares about ICBM's and PСB's. And then I get pregnant and find out your biggest goal in life is getting buried in Arlington National Cemetery."

"Sure, Raine, good old girl. Razz me for being patriotic."

"Air Force," I said. "Couldn't they have found a more attractive name?"

"It's a patriotic thing you don't understand the first thing about because you're not a patriotic person. The whole country could go down the tubes, as far as you're concerned."

"Not every truth can be blown on a trumpet," I said.

"It's scary to think that you have actually managed to replicate yourself."

I started humming. He took a few deep breaths. I really, really, really felt like I was in jail. I remembered when our relationship ended how I had cried and burned his photograph and reread my journal about all the good times we had had and listened over and over again to Robert Johnson singing the Bedspring Blues. I looked around the room. I stared at the light fixture full of fly carcasses and the poster of Leonard Zinsmeister, who was wanted for murder in the State of Alabama. "So how's your motorcycle?" I said.

"Hey-didn't we have some great times?" he said. "I loved whizzing around the city on that thing with your pretty arms around my waist."

"Yeah," I said. "There's energy in innocence."

"I'm still Alvy's father, whether you like it or not."

"I've made Mary his father," I said. "I want Alvy be the child sewn inside Zeus' leg."

He laughed this real cottony laugh he must have learned down at the old canteen. "Mary?"

"Yes, Mary. Do you mind?"

"Mary's a woman."

I knew he loved drinking nectar from golden goblets filled to the top by lesser goddesses, so I picked up the plastic carafe on the 
table, refilled his water cup and said, "Theodore, remember how you wanted to send Alvy to the landfill in a Hefty bag?"

"You think abortion's some terrible crime?" he said. "It's actually perfectly legal."

"The best way to make your dreams come true is to wake up," I said.

After seeing T-Bone, Wanda started to look very appealing to me. Here T-Bone was all spiffed up in his uniform with his perfect posture and his buzzed-off hair and his big fresh-faced smile but without an ounce of compassion in his heart for Alvy or me-and here Wanda was, a little spent maybe, a little dogged-out, but when I told her how much I missed Alvy, her eyes actually filled up with tears. She spent her life trying to make men happy-men who couldn't get happy at home. And she didn't contribute one penny to the defense budget.

Late at night when it was quiet and the lights were out and you could actually smell a smoky candlelight man scent in our cell, I told Ruby and Wanda all about love. And what I told them was this: that even though I cringe when I see people all dressed alike, I hate things flying through the air, I despise war and I'm terrified of nukes, somehow I came to love this military guy. The night he told me he was planning to join the Air Force, I sat down and looked at him. He had nice chocolate-colored eyes and his hair was a mess from wearing his motorcycle helmet and he was wearing these darling green suspenders. I pictured him in a crewcut, and I wanted to go with him off to Ellsworth Air Force Base because I couldn't stand the thought of not being with him. It may be the graumiest thing in creation to bag your convictions for a guy, but that's the way it was, and the way it always is with love.

"So what happened?" Wanda asked me.

"I became the virgin being sacrificed to the minotaur. Theodore turned out to be really shoddy goods," I said, remembering his rapid slide down the rainbow into the cave filled with black spirits. "But it's okay. Everyone separates eventually, one way or another, but that doesn't mean anything. Because the point is, if love is offered to you, and you say yes to it, that's enough. And when I'm old and I wake up one morning and say to myself, "Uh-oh-time to cover the bird,' at least I'll know I spent some time chirping." 
"You are weird," Wanda said, and they both fell silent, thinking of some old love of theirs, I guess, and I sat there thinking about TBone now that I wasn't under his spell any more. I was glad to be rid of him, except I'd lie in my bunk some nights and miss the feeling of loving. I'd think of a balloon being held in the fat, sticky hand of a two-year-old, and the balloon and the kid toddle along in a kind of rapture until the kid lets go of the balloon and it floats off into space. Maybe to float away is a beautiful thing, maybe adventure is calling and freedom is exciting, but the balloon liked it better being clutched in the gooey hand. It's the clutching that's wonderful, that feels so good. It's the not being free. We know it's not good for us but it feels so much better than just drifting through the universe like an unowned balloon.

"So why didn't you just get it on with this guy?" Ruby said, brushing the salt off a potato chip. "Why'd you bother to steal the Sherman tank?"

I stood up and smoothed out my uniform, realizing that this was my moment. "Nobody can understand why I'd try to steal a tank, but I'm young, and I felt like saying to the adults, look at us. Here we are-your creation. Armored children. You can yell, 'Get out of that tank, what if the police see you, what will the neighbors think? You'll be expelled from school!' Being expelled from my body is what concerns me-thrown out for too much strontium-9o and not enough oxygen, cast out like a drunk out of a bar."

"Uh-huh," Wanda said.

"Whatever," Ruby said. She yawned. I wasn't tired. I sat around reading The Celibate Woman's Journal and thinking about stealing the tank and feeling kind of proud of it - like at last I had learned to speak some foreign language or something. 